\title{
Pengaruh Pemberian Ekstrak Meniran Terhadap Ekspresi MMP 9 Dan Luas Lesi Endometriosis Pada Mencit Model Endometriosis
}

\author{
Stefani Angel Kumalasari ${ }^{1}$, Hendy Hendarto ${ }^{2}$, idjiati $^{3}$ \\ ${ }^{1}$ Mahasiswa Magister Ilmu Kesehatan Reproduksi, Fakultas Kedokteran, Universitas Airlangga \\ Surabaya \\ ${ }^{2}$ Departemen Obstetri Dan Ginekologi, Fakultas Kedokteran, Universitas Airlangga, \\ RSUD Dr. Soetomo \\ ${ }^{3}$ Departemen Embriologi Veteriner, Fakultas Kedokteran Hewan, Universitas Airlangga e-mail : \\ stefaniangel11@gmail.com
}

\begin{abstract}
Abstrak
Pada endometriosis, ekspresi MMP 9 ditemukan dalam konsentrasi yang lebih tinggi.Sekresi MMP 9 disebabkan oleh aktivasi ROS di rongga peritoneum dan menyebabkan peningkatan stres oksidatif. Peningkatan aktivitas MMP 9 pada endometriosis dapat memfasilitasi invasi yang mengakibatkan pembentukan lesi endometriosis. Tujuan penelitian ini adalah untuk mengetahui pengaruh ekstrak meniran (Phyllanthus niruri L.) pada dosis 14,28 dan $56 \mathrm{mg} / 20 \mathrm{gBB}$ terhadap ekspresi MMP 9 dan luas lesi endometriosis pada mencit model endometriosis. Penelitian ini merupakan penelitian eksperimental laboratorium. Dua puluh empat tikus betina digunakan sebagai sampel dan dibagi menjadi 4 kelompok: 1 kelompok kontrol dan 3 kelompok perlakuan. Keduanya, kelompok kontrol dan kelompok perlakuan diinduksi dan dijadikan model endometriosis selama 14 hari. 14 hari berikutnya, Na-CMC 0,5\% diberikan kepada kelompok kontrol, sedangkan ekstrak Phyllanthus niruri L. pada dosis 14, 28 dan 56 mg / 20 gBB diberikan kepada kelompok perlakuan secara oral. Luas lesi endometriosis pada rongga peritoneum diperiksa. Hasil penelitian ini menunjukkan bahwa ada perbedaan yang signifikan pada ekspresi MMP 9 dengan rata-rata $( \pm S D)$ K1, K2, K3, K4 sebesar 2.19 $\pm 1.77,0.19 \pm 0.13$, $0.14 \pm 0.13,0.08 \pm 0.14$ dan luas lesi endometriosis pada K1, K2, K3, K4 adalah 120.04 \pm 100.09 , 73.86 $\pm 36.72,69.08 \pm 15.73,25.53 \pm 3.51$. Kesimpulannya, ekspresi MMP 9 dan lesi endometriosis secara signifikan lebih rendah pada kelompok yang diobati dengan ekstrak Phyllanthus niruri L. herbal.
\end{abstract}

Kata kunci : ekstrak meniran, endometriosis, ekspresi MMP 9, luas lesi endometriosis 


\begin{abstract}
On endometriosis, expression of MMP 9 found in higher concentration. MMP 9 secretion is caused by the activation of Reactive Oxygen Species (ROS) release in the peritoneal cavity and causes increased oxidative stress. Increased MMP 9 activity in endometriosis can facilitates invasion resulting in the formation of endometriosis lesions. The objective of this study was to know the effect of Phyllanthus niruri L. extract at dose 14, 28 and $56 \mathrm{mg} / 20 \mathrm{~g}$ weight on expression of MMP 9 and endometriosis lesion vast on mice Mus musculus with endometriosis. This study was a laboratory experimental research. Twenty four mice were used as samples and divided into 4 groups : 1 control group and 3 treatment groups. Both of control group and treatment groups were induced as model of endometriosis for 14 days. The next 14 days, Na-CMC $0.5 \%$ was given to control group, while Phyllanthus niruri L. extract at dose 14, 28 and $56 \mathrm{mg} / 20 \mathrm{~g}$ weight were given to treatment groups orally. Endometriosis lesion vast on peritoneal cavity were examined. Result showed that there was significantly differences on MMP 9 expression with mean $( \pm S D)$ in $\mathrm{K} 1, \mathrm{~K} 2, \mathrm{~K} 3, \mathrm{~K} 4$ are $2.19 \pm 1.77,0.19 \pm 0.13,0.14 \pm 0.13,0.08 \pm 0.14$ and endometriosis lesion vast in $K 1, K 2, K 3, K 4120.04 \pm 100.09$, 73.86 $\pm 36.72,69.08 \pm 15.73,25.53 \pm 3.51$. in conclusion, the expression of MMP 9 and endometriosis lesion vast are significantly lower in groups treated with Phyllanthus niruri L. herbs etanol extract.
\end{abstract}

Keywords : Phyllanthus niruri L. extract, endometriosis, MMP 9 expression, endometriosis lesion vast

\section{PENDAHULUAN}

Endometriosis adalah kelainan reproduksi multifaktorial yang kompleks yang ditemukan $10-15 \%$ pada wanita dewasa dengan rentang usia antara 25-35 tahun. Kelainan ini terjadi ketika kelenjar endometrium dan stroma tumbuh secara ektopik pada permukaan ovarium, peritoneum pelvis, saluran tuba, dan rahim (Cureton, 2013).

Endometriosis merupakan penyebab umum morbiditas pada wanita usia reproduktif (Giudice, 2010). Endometriosis telah ditemukan pada 6-10\% dari wanita usia prodeuktif, sekitar $50-60 \%$ dari wanita dan remaja perempuan ditemukan dengan nyeri panggul, dan terdapat sekitar 50\% wanita yang ditemukan dengan infertilitas (Ozawa et al,. 2006). Angka kejadian endometriosis ditemukan meningkat setiap tahunnya, akan tetapi data pastinya masih belum diketahui. Pada penilitiannya, Jacob (2007) menuliskan bahwa angka kejadian endometriosis di Indonesia belum bisa diperkirakan karena masih belum ada studi epidemiologik yang dilakukan. Berdasarkan dari data di rumah sakit, diketahui angka kejadian endometriosis sekitar 13,6 - 69,5\% pada kelompok endometriosis dengan infertilitas. Bila persentase tersebut dihubungkan dengan jumlah penduduk yang ada, maka dapat diperkirakan sekitar 13 juta penderita endometriosis terjadi pada wanita usia produktif (Widhi, 2007).

Penatalaksaan pada penderita endometriosis digolongkan menjadi dua yaitu penatalaksaan medis dan penatalaksanaan bedah. Penatalaksaan medis pada penderita endometriosis dilakukan dengan pemberian terapi hormonal dan analgesik seperti nonsteroid anti-inflamatory drugs (NSAIDs). Pemberian terapi hormonal pada penderita endometriosis dapat meminimalisir nyeri dan progresivitas penyakit, akan tetapi pemberian terapi ini masih memiliki efek samping jika diberikan dalam jangka panjang. Efek samping yang dapat terjadi diantaranya adalah hipoestrogen yang dapat menghambat folikulogenesis dan ovulasi (Guyton and Hall, 2012).

Berdasarkan hal tersebut telah banyak penelitian dilakukan untuk mencari obatobat alternative dalam menekan progresivitas penyakit endometriosis dengan efek samping minimal. Berbagai penelitian dilakukan untuk mencari sel, sitokin, gen ataupun enzim yang berperan pada endometriosis dan dianggap berpengaruh terhadap pathogenesis dan progresivitas endometriosis. Salah satu enzim yang ditemukan berpengaruh pada endometriosis adalah matrix metalloproteinase 9 (MMP 9) (Weigel, 2012). Endometrium pada endometriosis mengalami peningkatan ekspresi atas grup spesifik enzim proteolitik yaitu Matrix Metalloproteinase (MMPs) dan Tissue 
Inhibitor Matrix Metalloproteinase (TIMPs), akibatnya terjadi implantasi sel endometrium ektopik. Misregulasi dari sintesis MMP dan sekresi dari lesi endometriosis bergabung dengan sejumlah TIMP-1 pada cairan peritoneum, kemudian mengubah komponen matriks fungsional disekitar cairan peritoneum dan menginduksi perilaku agresif serta memfasilitasi invasi sel ektopik (Liu et al., 2002).

Matrix metaloproteinase (MMPs) merupakan enzim proteolitik yang memiliki peran penting dalam pemodelan ulang matriks ekstraselular pada jaringan normal, namun juga berkontribusi pada patologi seperti invasi tumor (Matrisian, 1992). Matrix Metaloproteinase (MMP) adalah enzim entero peptidase kalsium yang teraktifasi oleh seng, berfungsi untuk mendegradasi atau menghancurkan matrik ekstra seluler seperti kolagen, elastin, gelatin, matrik glikoprotein dan proteoglikan. Peningkatan ekspresi MMP 9 dapat menyebabkan kelainan patologis sehingga fungsi homeostatis terganggu. Matrix metalloproteinase 9 (MMP 9) adalah salah satu dari keluarga MMP yang mengandung gelatinase. Ekspresi dari MMP ini pada endometrium dengan endometriosis adalah miss-regulate dan dapat berkontribusi pada pembentukan lesi endometriosis ektopik di rongga peritoneum (Osteen, 1996; Cox, 2000; Bruner, 1997).

Pada penelitian sebelumnya menyatakan bahwa ekspresi MMP 9 ditemukan meningkat pada sel endometriosis ektopik. Sama hal nya dengan sel tumor atau kanker, sel endometrium ektopik juga dapat berdifusi, metastasis dan menginvasi jaringan dan organ target dengan bantuan MMP 9 (Hu, 2012; Weigel, 2012; Chen,2010). Penelitian serupa yang dilakukan oleh Liu et al. (2002) juga menemukan peningkatan ekspresi dari MMP 9 pada lesi endometriosis. Peningkatan MMP 9 dihubungkan dengan peningkatan luas lesi endometriosis, utamanya pada rongga peritoneum (Kaylon, 1997). Penelitian lain yang dilakukan oleh Annas (2014) membuktikan adanya peningkatan ekspresi Prostaglandin-E2 (PGE2), MMP 9 dan luas lesi endomteriosis pada mencit model endometriosis. Sitokin dan hormon steroid meregulasi produksi MMP dan penghambatnya TIMP yang juga berperan dalam invasi sel endometrium ke mesotel. Hormon progesterone dapat menghambat sekresi dari MMP. Oleh karena itu pada jaringan yang kurang sensitif akan hormon progesterone dan adanya aktivitas sitokin yang meningkat akan menstimulasi peningkatan aktivitas MMP di endometriosis dan memudahkan invasi sehingga mengakibatkan terbentuknya lesi endometriosis (Kyama et al., 2003; Rizk and Abdalla, 2003). Sekresi MMP 9 diakibatkan oleh teraktivasinya pelepasan Reactive Oxygen Species (ROS) di rongga peritoneum dan menyebabkan oksidatif stres meningkat (Snehasikta, 2008).

Tumbuhan telah diketahui memiliki banyak manfaat dalam menjaga kesehatan masyarakat, khususnya dinegara berkembang. Menurut WHO, di Negara berkembang mayoritas penduduknya menggunakan pengobatan tradisional ( $\pm 80 \%$ ). Obat tradisional lebih banyak dipilih dibandingkan dengan obat modern karena efek samping yang mungkin ditimbulkan. Sedangkan obat tradisional yang terbuat dari herbal diketahui memiliki efek samping yang lebih kecil. Obat tradisional telah banyak digunakan di masyarakat dan terbukti lebih menguntungkan dibandingkan dengan obat modern. Tanaman yang berkhasiat sebagai obat herbal salah satunya adalah ekstrak phyllanthus niruri (meniran). Meniran adalah tanaman obat yang mengandung senyawa lignin, alkaloid, flavonoid dan triterpenoid. Kandungan dari senyawa flavonoid dalam meniran ini memiliki aktivitas sebagai antioksidan dimana mekanisme kerja antioksidan ini dapat menstimulasi enzim glutathione stimulase dan SOD sehingga dapat menghambat produksi radikal hidroksil. Secara tidak langsung, pemberian ekstrak meniran ini akan menghambat pembentukan ROS, mengurangi terbentuknya oksidatif stress, peningkatan MMP 9 dan peningkatan luas lesi endometriosis (Triarsari, 2009). Penelitian Shokunbi dan Odetola (2008) tentang efek perlindungan ekstrak meniran pada kerusakan histologis lambung tikus melalui aktivitas antioksidannya berhasil membuktikan bahwa pemberian ekstrak meniran dosis $500 \mathrm{mg}$ dan $1000 \mathrm{mg}$ pada tikus sangat efektif. Pada penelitian ini menggunakan dosis ekstrak meniran 14,28 dan $56 \mathrm{mg} / 20 \mathrm{gBB}$ mencit dari hasil 
konversi pada penelitian yang telah dilakukan oleh Shokunbi dan Odetola (2008) di atas.

Penelitian tentang tanaman herba yang dapat digunakan sebagai obat tradisional perlu dikembangkan agar dapat dipertanggungjawabkan secara ilmiah dan dapat bermanfaat bagi masyarakat. Berdasarkan hal itu, penulis tertarik untuk melakukan penelitian tentang pengaruh pemberian ekstrak meniran terhadap ekspresi MMP 9 dan luas lesi endometriosis pada mencit model endometriosis.

\section{TINJAUAN TEORI \\ 2.1 Endometriosis}

Endometriosis merupakan suatu keadaan terdapatnya jaringan endometrium (kelenjar dan stroma) di luar kavum uteri. Jaringan endomerium dapat ditemukan pada permukaan ovarium, peritoneum, dan rahim (Wiknjosastro, 1999).Patofisiologi terjadinya endometriosis masih belum pasti, akan tetapi terdapat banyak teori yang dinyatakan merupakan penyebab dari endometriosis. Etiologi dari endometriosis yang telah diketahui antara lain adalah sebagai berikut : regurgitasi haid,gangguan imunitas, luteinized unruptured follicle (LUF) dan disfungsi ovarium (Sourial et al., 2014).

Darah haid yang berbalik ke rongga peritoneum mampu berimplantasi padapermukaan peritoneum dan merangsang metaplasia peritoneum, kemudian merangsang angiogenesis. Lesi endometriosis terbentuk jika endometrium menempel pada selaput peritoneum. Hal ini terjadi karena pada lesi endometriosis terdapat protein intergin dan kadherin yang berpotensi terlibat dalam perkembangan endometriosis. Molekul perekat haid seperti cell adhesion molecules (CAMs), hanya ada di endometrium dan tidak berfungsi pada lesi endometriosis (Bulun, 2009).

Aktivitas morfologis endometrium terlaksana di dalam lapisan superfisial oleh pradesidualisasi dan perdarahan haid. Peritoneum bereaksi terhadap serpihan darah haid, berupa berhentinya perekatan sel-sel endometrium yang viabel ke peritoneum, yang kemudian dapat berubah bentuk menjadi lesi endometriosis. Dalam hal ini ikut berperan faktor imunologi. Sistem imunitas yang terdapat dalam aliran darah peritoneal berupa sel limfosit B,T dan Natural Killer (NK). Kemudian terjadi pengaktifan makrofag, namun tidak dapat membersihkan rongga pelvik dari serpih darah haid. Aktifitas sel NK menurun pada penderita endometriosis sehingga menyebabkan penurunan imunitas seluler (Bulun, 2009).

System imun berperan penting, pengaturan respon imun dilakukan oleh sel T yang dikenal sebagai sel $\mathrm{T}$ regulator. Sel $\mathrm{T}$ regulator ini berperan dalam menjaga keseimbangan dari sel Th1 dan sel Th2.Respon imunitas selular berfungsi sebagai pertahanan terhadap mikrooeganisme yang hidup intaseluler. Limfosit $\mathrm{T}$ atau sel $\mathrm{T}$ ini juga memiliki peranan yang sangat dalam respon imunitas selular. Sel $\mathrm{T}$ memiliki fungsi sebagai berikut : membantu sel B memproduksi antibody, mengenali sel yang terinfeksi virus dan menghancurkanya serta untuk mengaktifkan fagositosis makrofag. Sel T ini terbentuk di dalam sumsum tulang tetapi dan berproliferasi dalam kelenjar timus dan dipengaruhi oleh banyak factor yang ada di kelenjar timus. Kebanyakan dari sel timus tersebut mati (90-95\%) dan hanya sebagian kecil saja yang berkembang dan menjadi matang kemudian meninggalkan timus bergerak memasuki sirkulasi dan kelenjar getah bening. Sel $\mathrm{T}$ mendapatkan penanda $\mathrm{CD}$ (cluster of differentiation) dan antigen spesifik dan menjadi toleran terhadap dirinya di dalam timus.

Endometriosis merupakan penyakit yang bergantung dengan kadar estrogen akibat P450 aromatase dan defisiensi 17 betahidrohidroksisteroid dehidrogenase. Aromatase mengkatalisis sintesis estron dan estradiol dari androstenedion dan testosteron dan berada pada sel retikulum endoplasma.Pada sel granulosa 17 beta hidroksisteroid dehidrogenase mengubah estrogen kuat (estradiol) menjadi estrogen lemah (estron)(Sourial et al., 2014).

Endometrioma dan invasi endometriosis ekstraovarium mengandung aromatase kadar tinggi, faktor pertumbuhan, sitokin dan beberapa faktor lain berperan sebagai pemacu aktivitas aromatase melalui jalur cAMP. Hal ini menunjukkan adanya resistensi selektif gen sasaran tertentu terhadap kerja progesteron. Resistensi juga terjadi dilihat dari gagalnya endometriosis untuk beregresi dengan pemberian progestin (Bulun, 2009). 
Penatalaksanaan endometriosis masih memiliki banyak kekurangan. Saat ini penatalaksanaan dari endometriosis diberikan sesuai dengan gejala yang dikeluhkan pasien, keparahan gejala, letak endometriosis, tujuan pengobatan dan keinginan pasien dalam mempertahankan fertilitas (Mohamed, 2010).

Anamnesis yang dapat membantu diagnosa endometriosis antara lain adanya riwayat nyeri yang berhubungan dengan siklus haid, nyeri pelvik kronik, dispareunia, dischezia, infertilitas atau perdarahan yang tidak teratur. Salah satu keluhan yang paling sering dialami wanita dengan endometriosisadalah nyeri pelvik kronik mencakup dismenorea yang paling sering dilaporkan. Meskipun demikian dismenorea tidak dapat secara pasti memprediksi endometriosis.

\subsection{MMP 9}

Matrix metalloproteinase adalah enzim yang mampu mendegradasi makromolekul matriks ekstrasel, termasuk kolagen. Matriks metalloproteinase (MMP) ini juga disebut sebagai matriksin yang berperan penting dalam breakdown dan remodeling matriks ekstrasel (ECM). Matrix metaloproteinase 9 (MMP 9) adalah salah satu anggota keluarga MMP. MMP adalah keluarga besar endopeptidase bergantung seng yang mencakup kolagenase, gelatinase, stromelysin, metalloelastase dan MMPs tipe membran. MMP 9 terdiri dari satu N-terminal signal sequence (pre domain) yang mengeluarkan protein langsung ke reticulum endoplasma. Pre domain di ikuti oleh propeptide domain yang merupakan enzyme maintains-latency sebelum pecah, dan domain katalitik yang terdiri dari conserved zinc binding region. Juga dijumpai hemopexin/vitronectin-like domain, yang berhubungan dengan domain katalitik dengan linker region (Collette et al., 2006).

MMP 9 dapat mendegragasi kolagen tipe IV dan juga dapat mengaktivasi factor pertumbuhan seperti proTGF- $\beta$ dan proTNF- $\alpha$. MMP 9 juga mempunyai peranan yang kompleks, termasuk degradasi matriks ekstraseluler, pelepasan substansi proangiogenik, sekresi growth factor, integrin dan molekul adesi, serta menimbulkan efek keseimbangan antara proangiogenik dan antiangiogenik. MMP 9 dapat meningkatkan kemampuan angiogenesis VEGF dan mempunyai efek langsung terhadap sel endothelial yang diperlukan untuk migrasi sel dan pembentukan saluran (Liu et al., 2015).

Aktivitas MMP 9 di atur pada tiga tahap, yaitu : transkripsi, aktivasi zimogen precursor, dan inhibisi oleh inhibitor terutama TIMP dan proteinase inhibitor nonspesifik. Aktivasi ekspresi MMP 9 dapat dikontrol pada tingkat transkripsi gen oleh aktivasi proenzim dan inhibitor spesifik dan non spesifik.

Selain perannya di dalam rahim di bawah keadaan fisiologis normal, ekspresi MMP 9 yang telah berubah juga dikaitkan dengan patologi uterus yang biasa ditemukan seperti : perdarahan uterus disfungsional atau perdarahan, endometriosis, infertilitas,leiomioma dan kanker endometrium. Penelitian yang dilakukan Liu $e t$ al. (2015) membuktikan bahwa ekspresi MMP 9 pada penderita endometriosis ditemukan lebih tinggi dibandingkan pada kelompok kontrol.Tingginya ekspresi MMP 9 dipengaruhi oleh lokasi lesi dan stadium dari endometriosis. Pasien dengan lesi endometrium ektopik memiliki ekspresi MMP 9 yang tinggi.

\subsection{Luas Lesi Endometriosis}

Sel endometrium yang normal dapat keluar dari uterus dan berimplantasi pada jaringan diluar uterus kemudian berkembang menjadi lesi endometriosis. Keluarnya sel endometrium dari uterus dapat terjadi secara refluks atau retrogate melalui tuba fallopi saat menstruasi. Selain itu, keluarnya sel endometrium dari uterus dapat juga disebabkan oleh proses persalinan seperti seksio saesaria dengan adanya luka (insisi) dan pada saat persalinan normal dengan adanya robekan pada jalan lahir atau dilakukannya episiotomy. Keluarnya sel endometrium ini juga dapat melalui aliran darah dan limfe menuju organ target, organ target tersebut seperti paru-paru. Akan tetapi tidak semua sel endometrium yang berada diluar uterus dapat tumbuh dan berkembang menjadi lesi endometriosis (Hendarto,2015).

Retrogate menstruasi diperkirakan dialami oleh $\pm 76-90 \%$ wanita, akan tetapihanya $10-15 \%$ dari wanita dengan menstruasi retrogate yang menderita endometriosis. Menempel dan berkembangnya sel endometrium ini tidak terjadi pada semua jaringan tanpa adanya keadaan tertentu yang mendukungnya. Pada prosenya telah 
diterangkan bahwa banyak factor yang mendukung terjadinya endometriosis ini (Hendarto, 2015).

Lesi endometriosis atau sel disekitarnya dapat mensekresikan agen biokimia yang berperan pada proses terjadinya fibrosis dan perlengketan dari sel endometrium ektopik. Ada banyak mediator yang berperan dalam pembentukan perlengketan lesi endometriosis pada peritoneum seperti TGF $\beta$. Pada penelitian sebelumnya ditemukan adanya peningkatan TGF $\beta$ pada cairan peritoneum penderita endometriosis. Pada jaringan endometrium dan cairan peritoneum penderita endometriosis, growth factor berfungsi dalam proses proliferasi jaringan endometriosis. Penurunan jumlah apoptosis pada endometrium dan epitel endometriosis telah dilaporkan terjadi pada penderita endometriosis. Penurunan jumlah apoptosis ini yang disertai dengan peningkatan proliferasi mengakibatkan sel endometrium ektopik bertambah banyakdan bertahan lebih lama sehingga mendukung untuk terjadinya lesi endometriosis (Bedaiwy et al., 2002; Gupta et al., 2008). Sitokin dan hormone steroid meregulasi produksi MMP dan penghambatnya TIMP yang juga berperan dalam invasi sel endometrium ke mesotel. Hormone progesterone dapat menghambat sekresi dari MMP. Oleh karena itu pada ajaringan yang kurang sensitive akan hormone progesterone dan adanya aktivitas sitokin yang meningkat akan menstimulasi peningkatan aktivitas MMP di endometriosis dan memudahkan invasi sehingga mengakibatkan terbentuknya lesi endometriosis (Kyama et al., 2003; Rizk and Abdalla, 2003).

\subsection{Ekstrak Meniran}

Phyllanthus niruri atau yang lebih dikenal dengan meniran termasuk dalam famili Euphorbiaceae. Berbagai macam bahan organik telah ditemukan dalam herba meniran (Phyllantus niruri). Beberapa golongan zat utama yang terkandung adalah lignan, tanin, polifenol, alkaloid, flavonoid, terpenoid dan steroid.

Ekstrak meniran mengandung senyawa Flavonoid yang didalamnya terdapat zat aktif Quercetin merupakan antioksidan yang lebih kuat dibandingkan dengan vitamin $\mathrm{E}$ yang mampu meningkatkan imunitas tubuh. Senyawa flavonoid ini juga dipercaya dapat menghambat progresivitas endometriosis karena sifat antioksidan tersebut. Melalui enzim glutathion peroxidase dan SOD yang dapat menghambat produksi radikal hidroxil sehingga mengakibatkan terhambatnya pembentukan ROS (Harikumar, 2004). Ekstrak meniran (Phyllantus niruri L.) telah banyak digunakan dalam penelitian- penelitian tentang efek antioksidan, antiinflamasi, antibiotic dan juga sebagai imunomodulator.

\section{METODE PENELITIAN}

Penelitian ini merupakan penelitian eksperimental laboratorik, dengan pendekatan Post Test Only Control Group Design yang menggunakan mencit sebagai objek penelitian. Dalam penelitian ini, besar sampel yang digunakan adalah 24 mencit (Mus musculus)yang terdiri dari 1 kelompok kontrol dan 3 kelompok perlakuan. Mencit diaklimatisasi selama 7 hari, kemudian mencit tersebut dibuat menjadi model endometriosis dengan memberikan injeksi Siklosporin A secara intramuskular sebanyak $0,2 \mathrm{ml}$ pada hari-1, kemudian memberikan injeksi jaringan endometrium sebanyak $0,1 \mathrm{ml}$ secara intraperitoneal pada setiap mencit yang dijadikan sampel. Pada hari ke-5 mencit diinjeksi estrogen (ethynil estradiol) sebanyak $20.000 \mu$ dan pada hari ke-15 diharapkan mencit telah menjadi model endometriosis. Setelah itu mencit diberikan perlakuan selama 14 hari dengan memberikan $\mathrm{Na}$ CMC 0,5\% pada kelompok kontrol (K1) dan pada kelompok perlakuan (K2, K3 dan K4) akan diberikan ekstrak meniran dengan dosis 14 $\mathrm{mg} / 20 \mathrm{gBB}, 28 \mathrm{mg} / 20 \mathrm{gBB}$ dan $54 \mathrm{mg} / 20 \mathrm{gBB}$ mencit. Selanjutnya mencit dikorbankan dan diperiksa ekspresi MMP 9 dengan menggunakan metode imunohistokimia dan diperiksa luas lesi endometriosis dengan metode motic images pada hari ke 29.

Analisa data menggunakan software SPSS (Software Package for Social Science). Dilakukan uji normalitas menggunakan uji Kolmogorof Smirnov. Bila data berdistribusi normal dilanjutkan dengan uji Anova One Way. Bila data tidak berdistribusi normal akan dilanjutkan dengan uji Mann-Whitney. Untuk mengetahui adanya pengaruh masing-masing perlakuan dilakukan Uji T. Tingkat kemaknaan yang dipergunakan dalam penelitian ini sebesar 0,05 . 


\section{HASIL DAN PEMBAHASAN 4.1 Ekspresi MMP 9}

Matrix metalloproteinase 9 adalah salah satu anggota MMP yang berfungsi untuk mendegradasi kolagen tipe IV. Kolagen tipe IV ini adalah komponen utama dari matriks ekstraseluler. Kolagen ini berperan penting dalam membantu proses invasi dan metastase sel-sel tumor dan endometriosis (Nap et al., 2004). Ekspresi MMP 9 pada endometrium wanita dengan endometriosis ini berkontribusi dalam pembentukan lesi endometriosis ektopik pada rongga peritoneum (Sharpe, 2008).

Tabel 4.1 Rerata dan simpangan baku ekspresi MMP 9 pada mencit betina model endometriosis yang diberi ekstrak meniran pada mencit model endometriosis memiliki efektifitas yang sama. Beberapa penelitian sebelumnya menunjukkan bahwa ekspresi MMP 9 meningkat pada sel endometriosis ektopik

\begin{tabular}{|l|l|l|l|}
\hline \multicolumn{4}{|l|}{ Rerata ekspresi MMP 9 } \\
\hline K1 & K2 & K3 & K4 \\
\hline $2,19 \pm 1$ & $0,19 \pm 0$ & $0,14 \pm 0$ & $0,08 \pm 0$ \\
, 77 &, 13 &, 13 &, 14 \\
& & & \\
\hline
\end{tabular}

Hasil penelitian ini menunjukkan bahwa terdapat perbedaan ekspresi MMP 9 antara kelompok kontrol dengan kelompok perlakuan. Pada tabel 4.1 terlihat bahwa ekspresi MMP 9 lebih kuat pada kelompok kontrol dibandingkan pada kelompok perlakuan.

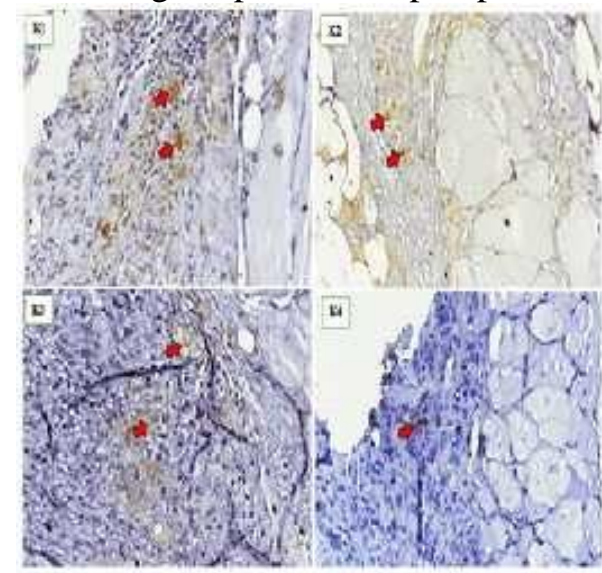

Gambar 4.1 Perbedaan ekspresi MMP 9 tiap kelompok menggunakan pewarnaan imunohistokimia dengan pembesaran 400x. Dari hasil penelitian ini juga kelompok perlakuan K2, K3 dan K4 memiliki ekspresi
MMP 9 yang lebih rendah dibandingkan dengan kelompok control K1. Pada kelompok perlakuan pemberian ekstrak etanol herba meniran K2, K3 dan K4 secara statistic, ekspresi MMP 9 pada kelompok ini berbeda secara bermakna dengan kelompok kontrol K1. Hasil dari penelitian ini menunjukkan bahwa pemberian ekstrak meniran dengan dosis $14 \mathrm{mg} / 20 \mathrm{gBB}, 28$ $\mathrm{mg} / 20 \mathrm{gBB}$ dan $56 \mathrm{mg} / 20 \mathrm{gBB}$ mencit mampu menurunkan ekspresi MMP 9. Ekspresi MMP 9 semakin lemah seiring dengan peningkatan dosis pemberian ekstrak etanol herba meniran. Berdasarkan tabel 5.2 dapat terlihat bahwa dari ketiga dosis pemberian ekstrak etanol herba meniran Sama hal nya dengan sel tumor atau kanker, sel endometrium ektopik juga dapat berdifusi, metastasis dan menginvasi jaringan dan organ target dengan bantuan MMP 9 (Hu, 2012; Weigel, 2012 Chen,2010).Penelitian serupa yang dilakukan oleh Liu et al. (2002) juga menemukan peningkatan ekspresi dari MMP 9 pada lesi endometriosis. Aktivitas MMP 9 juga dimodulasi oleh stress oksidatif dengan meningkatkan ROS (Paul, 2008).

Pada pasien dengan endometriosis telah dilaporkan adanya peningkatan produksi ROS oleh sel mononuclear di rongga peritoneum. Stimulasi dari makrofac di rongga peritoneum ini menginduksi pelepasan ROS (Agarwal, 2006). Penelitian serupa juga menyatakan bahwa efek antioksidan dari antiprogestin pada tikus model endometriosis berhasil menghambat progesifitas endometriosis (Stoeckemann etal., 1995). Kandungan antioksidan dalam vitamin $\mathrm{C}$ dan vitamin $\mathrm{E}$ telah terbukti memiliki efek dalam menghambat pembentukan lesi endometriosis pada pasien penderita endometriosis (Spitz, 2003). tersebut dapat menstimulasi enzim glutathione stimulase dan SOD sehingga dapat menghambat produksi radikal hidroksil. Sehingga pemberian ekstrak meniran ini dapat menghambat peningkatan ekspresi MMP 9. Hasil ini sesuai dengan penelitian efek antioksidan ekstrak meniran pada kerusakan lambung tikus yang menyatakan bahwa senyawa antioksidan yang terkandung dalam ekstrak meniran dapat meningkatkan enzim glutathione stimulase dan SOD (Shokubin and Odetola, 2008).

Meniran merupakan herba yang memiliki senyawa flavoid yang terkandung di dalamnya yang dapat berfungsi sebagai antioksidan. 
Penurunan ekspresi MMP 9 pada kelompok perlakuan ini karena ekstrak etanol herba meniran yang memiliki kandungan senyawa flavonoid sebagai antioksidan. Senyawa

\subsection{Luas Lesi Endometriosis}

Luas lesi endometriosis menggambarkan beratnya lesi endometriosis. Luasnya lesi endometriosis ini disertai dengan adanya ketersediaan pembuluh darah yang semakin meningkat. Luas lesi endometriosis pada penelitian ini di ukur dengan menggunakan skala millimeter dengan menghitung area inflamasi menggunakan program motic images. Pada penelitian ini, peneliti menggunakan luas lesi endometriosis pada peritoneum mencit model endometriosis.

Tabel 4.2 Rerata dan simpangan baku luas lesi endometriosis pada mencit model endometriosis yang diberi ekstrak meniran

\begin{tabular}{llll}
\multicolumn{4}{l}{ Rerata luas lesi endometriosis } \\
\hline $\mathrm{K} 1$ & $\mathrm{~K} 2$ & $\mathrm{~K} 3$ & $\mathrm{~K} 4$ \\
\hline 120,04 & $73,86 \pm$ & $69,08 \pm$ & $25,53 \pm$ \\
\pm & 36,72 & 15,73 & 3,51 \\
\hline
\end{tabular}

Pada tabel 4.2 menunjukkan perbedaan dari nilai rerata tiap kelompok, kelompok kontrol (K1) dan kelompok perlakuan (K2, K3 dan K4). Penurunan luas lesi endometriosis tersebut terlihat seiring dengan dosis ekstrak etanol herba meniran yang meningkat. Hasil dari analisis statistik uji t menunjukkan bahwa antara kelompok kontrol dengan kelompok perlakuan K4 terdapat hubungan yang bermakna dengan nilai $\mathrm{p}=0,043$ lebih kecil dari 0,05. Sedangkan pada kelompok perlakuan K2 dan K3 tidak terdapat hubungan yang bermakna. Selanjutnya dilakukan uji anova untuk mengetahui hubungan antar setiap kelompok dan didapatkan hasil yang signifikan dengan nilai $\mathrm{p}=0,000$ lebih kecil dari 0,05. Sehingga dapat disimpulkan bahwa antara $\mathrm{K} 1$ dengan $\mathrm{K} 2$, $\mathrm{K} 3$ dan $\mathrm{K} 4$ terdapat perbedaan yang signifikan.

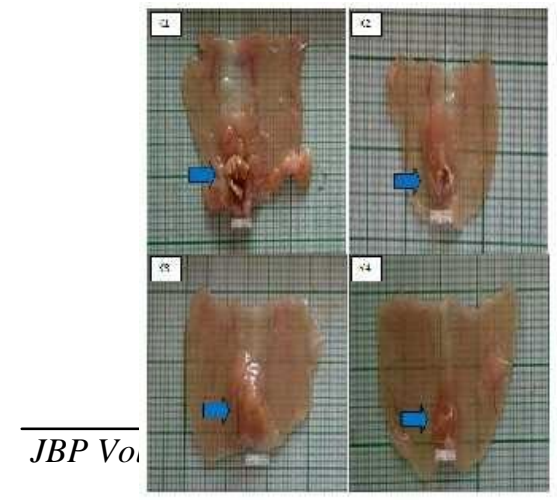

Gambar 4.2 Perbedaan luas lesi endometriosis (yang ditunjuk tanda panah) pada mencit model endometriosis

Peningkatan aktivitas MMP 9 di endometriosis memudahkan invasi sehingga mengakibatkan terbentuknya lesi endometriosis (Kyama et al., 2003). Pembentukan lesi endometriosis ini membutuhkan kaskade factor angiogenik, seperti VEGF, sitokin dan metalloproteinase. Keterkaitan antara faktorfaktor tersebut dapat meningkatkan pembuluh kapiler dari pembuluh darah yang sudah ada untuk pengembangan lesi endometriosis (Giudice et al., 2010).

Penelitian lain membuktikan bahwa ROS berperan dalam meningkatkan pertumbuhan dan adhesi sel endometrium di rongga peritoneum pada endometriosis (Arumugam, 1995; Alpay, 2006). Collette et al (2004) dalam penelitiannya menjelaskan bahwa aktivitas MMP-9 yang tinggi berperan dalam peningkatan aktivitas proteolitik dan memainkan peran penting dalam remodelling vaskular selama invasi jaringan dalam proses pembentukan lesi endometriosis. Dari hasil penelitian ini diketahui bahwa penurunan ekspresi MMP 9 ini seiring dengan adanya penurunan luas lesi endometriosis. Hal ini sesuai dengan penelitian sebelumnya bahwa senyawa antioksidan dalam curcumin mampu memodulasi aktivitas MMP 9 sehingga dapat meregresi lesi endometriosis (Snehasikta ,2008). Dalam penelitian tersebut juga dijelaskan sekresi MMP 9 diakibatkan oleh teraktivasinya pelepasan Reactive Oxygen Species (ROS) di rongga peritoneum dan menyebabkan oksidatif stres meningkat (Snehasikta, 2008). Sekresi MMP 9 yang berlebihan ini dapat meningkatkan pertumbuhan lesi endometriosis (Arumugam, 1995; Alpay, 2006; Snehasikta,2008).

Pemberian ekstrak etanol herba meniran pada mencit model endometriosis dosis 14,28 dan $56 \mathrm{mg} / 20 \mathrm{gBB}$ dapat menurunkan luas lesi endometriosis yang terbukti secara deskriptif. Akan tetapi dosis yang paling efektif untuk menurunkan luas lesi endometriosis adalah dosis $56 \mathrm{mg} / 20 \mathrm{gBB}$ 
mencit dengan nilai signifikansi 0.007 lebih kecil dari 0,05. Luas lesi endometriosis pada kelompok perlakuan K2, K3 dan K4 lebih kecil dari kelompok kontrol K1 membuktikan bahwa pemberian ekstrak etanol herba meniran dapat menurunkan luas lesi endometriosis. Hal ini terjadi karena pemberian ekstrak etanol herba meniran dapat menekan pembentukan lesi endometriosis.

\section{KESIMPULAN DAN SARAN}

Pemberian ekstrak meniran (Phyllanthus niruri L.) dosis $14 \mathrm{mg} / 20 \mathrm{gBB}, 28$ $\mathrm{mg} / 20 \mathrm{gBB}$, dan $56 \mathrm{mg} / 20 \mathrm{gBB}$ pada mencit (Mus musculus) model endometriosis dapat menurunkan ekspresi MMP 9 dan luaslesi endometriosis. Dosis paling efektif yang dapat digunakan untuk menurunkan ekspresi MMP 9 dan luas lesi endometriosis adalah dosis paling tinggi dalam penelitian ini yaitu dosis $54 \mathrm{mg} / 20 \mathrm{gBB}$ mencit. Untuk penyempurnaan penelitian, perlu dilakukan penelitian lebih lanjut mengenai kemampuan ekstrak meniran dalam mengurangi progresifitas endometriosis dengan menggunakan parameter lain, misalnya dengan memeriksa kadar VEGF, TNF $\alpha$, IL 1, jumlah makrofag dan sebagainya.

\section{DAFTAR PUSTAKA}

Arumugam K and Dip YC. 1995. Endometriosis and infertility: the role of exogenous lipid peroxides in the peritoneal fluid. Fertil Steril 63,198-199.

Bedaiwy Mohamed A, Liu James. 2010. Pathophysiology, diagnosis, and surgical management of endometriosis: A chronic disease. SRM e-journal Vol. 8, No. 3, Aug 2010, 4-8.

Brack E. 1999. Encyclopedic Dictionary of Useful Plants of Peru.Cusxco and Peru : Feed Your Health.

Brittani Lauren Cureton. 2013. A Critical Review of Endometriosis Pathology. (Master's thesis). University of South Carolina.

Bruner, K.L., L.M. Matrisian, W.H. Rodgers, et al. 1997. Suppression of matrix metalloproteinases inhibits establishment of ectopic lesions by human endometrium in nude mice. J. Clin. Invest.

Bulun E.S. 2009. Endometriosis. N Engl J Med 2009; 360:268-279 January 15, 2009 DOI: $10.1056 / \mathrm{NEJMra0804690}$
Chen Q, Qiu N, Pu D, Zhou Y, Li T and Yang H. 2010. Change profiles in matrix metalloproteinase-2 and -9 in induced endometriosis in mice. J Huazhong Univ Sci Technolog Med Sci 30: 188-192, 2010.

Collette T, Maheux R, Mailloux $\mathrm{J}$ et al. 2006. Increased expression of matrix metalloproteinase-9 in the eutopic endometrial tissue of women with endometriosis. Hum Reprod 2006; 21:3059-3067.

Cox, K.E., M. Piva \& K.L. Sharpe-Timms. 2000. Differential expression of matrix metalloproteinase-3 (MMP-3) gene expression in endometriotic lesions as compared to endometrium. Biol. Reprod. In press

Cramer DW, Missmer SA. 2002. The epidemiology of endometriosis. Ann NY Acad Sci. 2002;955:11-22.

Donnez J, Van Langendonckt A, CasanasRoux F, Van Gossum JP, Pirard C, Jadoul P, Squifflet J and Smets M. 2002. Current thinking on the pathogenesis of endometriosis. Gynecol Obstet Invest 54 (Suppl 1),52-58.

Giudice Linda C. 2010. Endometriosis. N Engl J Med 2010;362:2389-98.

Hu X, Li D, Zhang W, Zhou J, Tang B and $\mathrm{Li}$ L. 2012. Matrix metalloproteinase-9 expression correlates with prognosis and involved in ovarian cancer cell invasion. Arch Gynecol Obstet 286: 1537-1543, 2012.

Jones RL, Findlay JK, Farnworth PG, Robertson DM, Wallace E \&Salamonsen LA. 2006. Activin $A$ and inhibin $A$ differentially regulate human uterine matrix metalloproteinases: potential interactions during decidualization and trophoblast invasion. Endocrinology 147 724-732.

Junieva P.N. 2006. Pengaruh Pemberian Ekstrak Meniran (Phyllanthus sp.) Terhadap Gambaran Mikroskopis Paru Tikus Wistar Yang Diinduksi Karbon Tetraklorida. Artikel. Semarang : Universitas Diponegoro

Kathy L Sharpe-Timms. 2008. Endometrial anomalies in woman with endometriosis. Dept of obstetrics and gynecology. University of Missouri-columbia

Liu XJ, He YL and Peng DX. 2002. Expression of metalloproteinase-9 in ectopic endometrium in women with endometriosis. Di Yi Jun Yi Da Xue Xue Bao 22,467 \pm 469 .

Manero M.G, Royo P, Olartecoechea B, Alcázar J.L. 2009. Endometriosis in a postmenopausal woman without previous 
hormonal therapy: a case report. Journal of Medical Case Reports 2009, 3:135.

Matrisian, L.M. 1992. The matrix degrading metalloproteinases. Bioassays

Mori K, Shibanuma M, Nose K. 2004. Invasive potential induced under long-term oxidative stress in mammary epithelial cells. Cancer Res 2004; 64:7464-7472.

Murphy AA, Palinski W, Rankin S, Morales AJ and Parthasarathy S. 1998. Evidence for oxidatively modified lipid-protein complexes in endometrium and endometriosis. Fertil Steril 69,1092-1094.

Nugroho T. 2003. Pengaruh Pemaparan Kombinasi Ekstrak Meniran (Phyllanthus niriri L.) dan Ekstrak Sirih (Piper betle L.) Terhadap Viabilitas Sel Tumor Adenocarsinoma Mammae Mencit C3H Secara Invitro. Tesis. Semarang : Universitas Diponegoro

Osteen K.G., K.L. Bruner \& K.L. SharpeTimms. 1996. Steroids and growth factor regulation of matrix metalloproteinases expression and the disease endometriosis. Sem. Reprod. Endocrinol.

Ozawa Y, Murakami T, Terada Y, Yaegashi N, Okamura K, Kuriyama S, Tsuji Ichiro. 2006. Management of the Pain Associated with Endometriosis: An Update of the Painful Problems. Tohoku J. Exp. Med 2006, 210, 175-188.

Pediana R. 2010. Efek Perlindungan Ekstrak Meniran (Phyllanthus niruri L.) Terhadap Kerusakan Histologis Lambung Mencit (Mus musculus) Yang Diinduksi Aspirin. Skripsi. Surakarta : Universitas Sebelas Maret

Pustovrh MC, Jawerbaum A, Capobianco E et al. 2005. Oxidative stress promotes the increase of matrix metalloproteinases -2 and -9 activities in the feto-placental unit of diabetic rats. Free Radic Res 2005; 39:1285-1293.

Rajagopalan S, Meng XP, Ramasamy S et al. 2003. Reactive oxygen species produced by macrophage-derived foam cells regulate the activity of vascular matrix metalloproteinases in vitro. Implications for atherosclerotic plaque stability. J Clin Invest 1996; 98:25722579.

Somerville RP, Oblander SA, Apte SS. 2003. Matrix metalloproteinases: old dogs with new tricks. Genome Biol 2003; 4:216.

Sourial S., Herbert V., Veith R.. 2014. Theories on the Pathogenesis of Endometriosis, International Journal of Reproductive Medicine. Volume 2014, Article ID 179515, 9 pages

Sudarsono, Agus P, Didik G dkk. 1996. Tumbuhan obat. Yogyakarta : UGM, Pusat Penelitian Obat Tradisional.

Sulaksana J. dan Jayusman D.I. 2004. Meniran, Budidaya dan Pemanfaatan Untuk Obat. Jakarta : Penebar Swadaya.

Wahyuningsih H.K. 2010. Pengaruh Pemberian Ekstrak Herba Meniran (Phyllanthus niruri L.) Terhadap Penurunan Kadar Asam Urat Darah Tikus Putih Jantan Hiperurisemia. Skripsi. Semarang : Universitas Sebelas Maret

Weigel MT, Krämer J, Schem C, Yang S, Fang Z, Gurates B, Tamura M,. 2012. Differential expression of $M M P-2, M M P 9$ and PCNA in endometriosis and endometrial carcinoma. Eur J Obstet Gynecol Reprod Biol 160: 74-78, 2012.

Widhi. 2007. Endometriosis: Dari biomolekuler sampai masalah klinis. Majalah Obstetri dan Ginekologi, 10(1): 43-50. 